\section{Ambient atmospheres: Exhibiting the immaterial in works by Italian Rationalists Edoardo Persico and Franco Albini}

\author{
Ross Jenner
}

\begin{abstract}
The (im)materiality of space
Ideas of "immateriality" in architectural modernity arose together with those of "space", the relation of immateriality/materiality paralleling that of space/mass. This pairing of matter with that "most immaterial of properties - 'space"” seems constitutive of modernity (Forty 2000: 256; see also Solà-Morales 1996: 93-95). Also generated in discourse around the beginning of the last century were notions such as atmosphere, ambience, envelopment, surroundings, context, environment, milieu, medium, habitat and setting.
\end{abstract}

Already in 1873, the philosopher Robert Vischer observed how a dreaming body "unconsciously projects its own bodily form - and with this also the soul - into the form of the object”. On this, he based his notion of (empathy) Einfühlung (1994: 92). Twenty years later, the art historian, August Schmarsow, who extended empathy from solids to void, was probably the first to treat bodily experience as central (1994: 286-87). That same year, 1893, the sculptor Adolf Hildebrand proposed space as continuity: "as a body of water", in which individual solids are immersed (1918: 28-29) - anticipating both Paul Valéry's understanding of architecture (as being "inside a work of man as fishes are in the sea, being entirely immersed in it, living in it, and belonging to it”, 1960 (1921): 102) and Peter Sloterdijk's notion of immersion, which embraces Valéry’s (Sloterdijk 2011: 106-109). Wishing to render space visible, Hildebrand implied that a void is not externally limited but "internally animated", and that "the boundary of an object is, strictly speaking, also the boundary of the body of air surrounding it” (1918: 239).

I examine here an atmospheric spatiality, an artistic set-up involving immersion, activation and relation within space. Such space as felt, in mood and affect, is, I will demonstrate, found in the works of Italian rationalists, Franco Albini and Edoardo Persico (his friend and mentor). In his exhibition and installation works, Albini developed felt space into one of relationships. Its appearance can be taken as an adumbration of the sort of atmospheres and scene settings Gernot Böhme proposes today. In Persico and Albini's works, the wish to make space visible emerges in two allied strategies, which focus this paper. First, showing space as a medium, or atmosphere - that is, making the immaterial material and establishing a blurring between substance and medium, mergence and emergence. Second, establishing a rapport or interplay, often by linear means, or a flickering reversal between mass and space, full and empty, present and absent, and between what is and what is not.

\section{Atmosphere and clearing}

In one sense, the first of these strategies was not new in the twentieth century. Atmosphere was, and remains, the key element in oriental art, ${ }^{1}$ just as smokiness was valorised in the Renaissance. In the sixteenth century, Daniele Barbaro wrote of painting made with contours soft and sfumati, which could bring one "to understand what is not seen", to experience "a most gentle receding, a delicacy on the horizon of our sight, which both is and is not” (1556: bk. 7, cap. V). At the same
1 "Atmosphere" demands a co-presence that necessarily engulfs the terms of any subject/object division. François Jullien notes: "[u]nlike the activity of cognition, 'atmosphere' could not be conceived in terms of the opposition between the objective and subjective. It is an influence that emerges from beings and things and is valid only by virtue of the impression in us: it e-manates or im-parts and hence circulates inseparably between what is neither 'that' nor 'us' anymore, something that, as a result, cannot recede into a 'what,' not even into the 'I don't know what.' Indeed an atmosphere is diffuse, disseminated, dispersed, elusive. Its presence cannot be isolated into determinate elements, it is both sparse and undelimitable. Above all, it is not assignable. Evasive, evanescent, it can be analysed not in terms of presence or essence, but only in terms of heaviness or valence, $e x$-haling, in-fluencing, in a nonontological mode, between 'there is' 'there is not'.' (Jullien 2009: 41) 
time, Giorgio Vasari wrote of parts of the body being revealed with "sweet and easy grace ... between the seen and unseen" (1550: 80).

At the beginning of architectural modernity, atmosphere re-emerged as a core concern. In 1851, Mary Merrifield used the term to describe the Crystal Palace, which,

is perhaps the only building in the world in which atmosphere is perceptible. ... To the spectator situated in the gallery at the eastern or western end, who looks directly before himself, the most distant parts of the building appear enveloped in a bluish haze, as if it were open to the air, the warm tint of the canvas and roof contrasts with the light blue colour of the girders into which it is insensibly lost, and harmonising with the blue sky above the transept, produces an appearance so pleasing, and at the same time so natural, that it is difficult to distinguish where art begins and nature finishes. $(1970(1851))^{2}$

The German publicist, Lothar Bucher, similarly wrote of a fairy-like impression, in which "all materiality is blended into the atmosphere" (1851: 174). Surprisingly, Gottfried Semper, the so-called "materialist", might have been the first to theorise the word "atmosphere" architecturally when he argued, 10 years after the Great Exhibition, that,

2 Jones provided a theoretical justification for the design in painterly terms: aerial perspective and Impressionist pointillism. He theorised his use of colour in the Crystal Palace using blue, red and yellow "in such relative quantities, as to neutralise or destroy each other, thus no one colour will be dominant or fatiguing to the eye, and all the objects will assist, and be assisted by, the colours of the building itself." (From "On the Decorations proposed for the Exhibition Building in Hyde Park" in Jones 1863: 11.) What resulted was an Impressionism/Divisionism: "The blending of the three primary colours in the roof of the nave, where the effect could be seen uninterruptedly, was most complete, and produced an artificial atmospheric effect of a most surprising kind." (From "An attempt to define the principles which should regulate the employment of colour in the decorative arts", read before the Royal Society of Arts, April 281852 in Jones 1863). Need one add that attention to atmosphere was, of course, already present in the Constable's "skying", Turner's atmospherics, and Ruskin's obsessions with clouds and weather in Modern Painters, The Queen of the Air and in The Storm Cloud of the Nineteenth Century?

3 Gernot Böhme remarks: "The term, itself, 'atmosphere', derives from meteorology and as a designation for an ambient quality has a number of synonyms that likewise connote the airy, cloudy, or indefinite: these include climate, nimbus, aura, fluid; and perhaps emanation could be counted among them as well. (Böhme 1998: 112)

On atmosphere as weather, perhaps the quintessentially British perception, see, for example: Forster 1815; John E. Thornes, 2008a and 2008b; Hamblyn 2001; Jankovic 2000; Ingold 2005, 2011 (115-135), 2012 and 2013; Connor 2010; Olwig 2011; Hill 2012.

For an approach to weather acknowledging emotions, see Böhme 2003.
Every artistic creation, every artistic pleasure, presumes a certain carnival spirit, or to express it in a modern way, the haze of carnival candles is the true atmosphere of art. The destruction of reality, of the material, is necessary if form is to emerge as a meaningful symbol, as an autonomous human creation. (2004: $\mathrm{n} .85,438-39)$

Richard Lucae, architect of the Frankfurt Opera House, described the Crystal Palace as a "piece of sculptural atmosphere" (1869) and Sigfried Giedion compared the airy, hovering and floating elements of the Crystal Palace with Turner's painting - in both, the effect was achieved "through a humid atmosphere which dematerialises the landscape and dissolves it into infinity" (1943: 191). In other words, weather, the condition of air in sunshine, rain, snow, or mist, renders space airlike, makes palpable the materiality of what appeared immaterial. ${ }^{3}$

The second strategy, the interplay between solid and void, present and absent might be termed design by erasure - that is, configuring the void by freeing, stripping and ridding space from solids. The word (space) Raum implies (clearing away) räumen, which "means: to rid, clear out, to free from wilderness" (Heidegger, following the Grimms' dictionary definition, 1973: 5). Heidegger explored this mode of clearing, spacing, making room and making space in an essay which accompanied lithographs by the Basque sculptor, Eduardo Chillida (see Prada 2009: 14, 16, $28,52)$. In architecture, it was promoted by Adolf Loos or, even earlier, by Joseph Paxton who strove to reduce engineered structure to the minimum of mass.

Both strategies are important in two of Persico's installations, which are very much concerned with space as atmosphere and with space as the relationship between mass and space, solid and void, material and immateriality. I will now locate concepts of atmosphere as (mood) stato d'animo and felt space in contemporary accounts of these works. From there, I will show how Albini could develop these themes into a notion of relational space in his exhibition and installation works. 
Critics noted an "impressionistic sensibility" in Persico's installations in the 1930s. In the Hall of the Gold Medals (1934) by Persico and Nizzoli and the Hall of Honour (1936), "the voids have a compositional value even more alive than the solids” (Carla Albini quoted in M. Albini 2006: 207). Bruno Zevi judged The Hall of the Gold Medals at the Exhibition of Italian Aeronautics in the new Palazzo dell'Arte in Milan "the only true invention, and thus the only original contribution to the language of architecture produced by Italy between the two wars" (1975: 203). The work commemorated the exploits in the First World War of the Italian aviators who received the prestigious Gold Medal. In Persico's design, documents in the form of photographs and artefacts were to speak for themselves (Persico 1968: 262-263).

Anna Maria Mazzucchelli ${ }^{4}$ described the exhibition in terms of atmosphere: "the heroes are exalted in a suggestive and moving climate" (1934: 534). Photographic panels, artefacts, and texts, mounted on a series of slender floor-to-ceiling scaffolds, created an "explosion of documents in space imbued with an unreal light; the delicate white outlines that cancel themselves out against the white of the walls, held between black ceiling and floor giving a sense of infinite horizon" (533). The uprights were laid out in strict files, implying indefinite horizontal and vertical extension. Minimally connected, they appeared to pass right through the confines of the room. The work was of utmost simplicity, but also of the utmost subtlety, putting into play a complex articulation of space. An abstract graph, for instance, was elided with a recurring figurative element: the box frame of the first bi-planes, in a spectral skeletal quality, at the threshold between oblivion and consciousness.

Persico's close associate, Giulia Veronesi, described the installation's “ineffable” colour ("colour" being an odd term since the entire installation was in black and white) and considered it "one of the purest and most transfiguring lyrical images of architecture" of its age, a work "intensely magical, in its musical accord of whites and blacks elevated in an unreal light (a blue air of luminous night) to create a dense and soft atmosphere of the mystery of death, of its distance ...” (1953: 108).
$4 \quad$ Mazzucchelli worked under Persico and Pagano at Casabella. See Astarita 1998.

Fig. 1 (right) Edoardo Persico, Marcello Nizzoli and Lucio Fontana (1934). Hall of the Gold Medals, Palazzo dell'Arte, Milan. [Edoardo Persico Scritti d'architettura (1927/1935), ed. Giulia Veronesi, Vallecchi Edittore, Florence, 1968:193]

Fig. 2 (left) Edoardo Persico, Marcello Nizzoli and Lucio Fontana (1934). Hall of the Gold Medals, Palazzo dell'Arte, Milan. [Edoardo Persico: Tutte le opere, ed. Giulia Veronesi, vol. 2. Edizioni di Comunità, Milan, 1964:178]
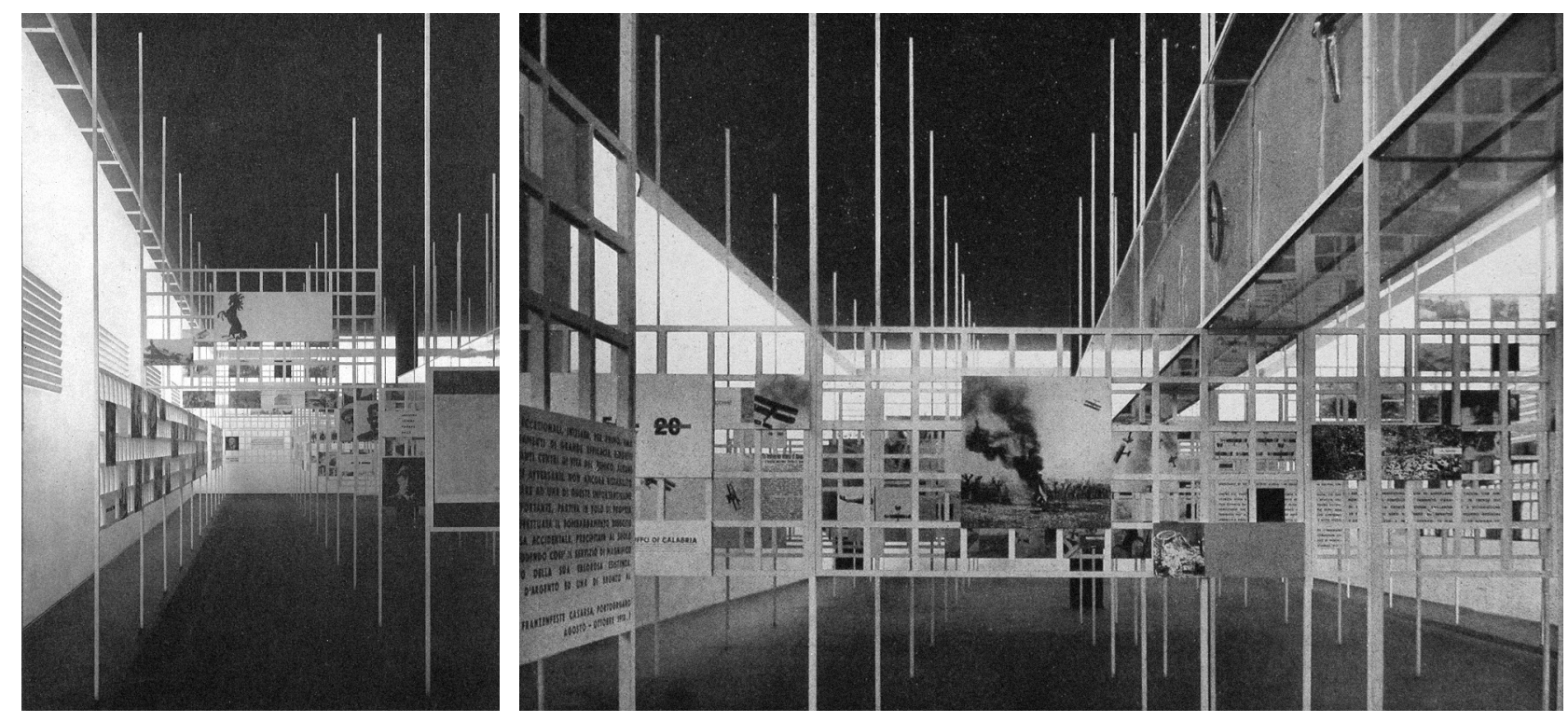


\section{The Hall of Honour}

The 1936 Milan Triennale culminated in Persico's last design, the Hall of Honour. Again, the design was perceived as a suspended atmospheric environment, the space of intercolumniation being its principal motif. The visitor was forced to filter through a narrow corridor between the lines of off-set panels to gain entry. Within was a space suffused with light, where, on pedestals, stood the statue of a goddess with two horses.

Again, the impact was of black and white. An "orgy of white, absolute white" is how Peter Meyer, Swiss editor of Das Werk, described it (1936: 314). Italian critic, Raffaello Giolli experienced atmosphere, immersion and loss of weight: his visitor is suddenly "engulfed by an unexpected atmosphere, in a moment, as if entering a painting or a poem: a lyrical moment". It is the "unexpected immersion in white that instantly makes us lose all sense of weight and all normal gauge of measure, carrying us into a fervent play of light" (1936: 14). ${ }^{5}$ The second effect was of blackness: the background of the installation was a black box, the blackened out walls of the hall in the Palazzo dell'Arte which housed it (Meyer 1936: 314).

A scenographic quality, reminiscent of De Chirico in its openly bared illusionism, was reinforced by the rows of off-set screens, producing the effect of continuous closure, from within and from without, but the air passed right through them. Giolli wrote of the screens" "breathing richness" creating "an unreal belt and a curtain of light”. Their doubling immediately created an unexpected dynamic. Another occurred when looking at the more distant planes, which "seem to be repeated in an hallucinating mirroring of themselves". Their flickering rhythm "opens and reopens continuously and amazingly” (1936: 18).

It is this filtering process that stirs the air and confounds perception. Giolli found that "the exuberant scale" of the room forced one "to look upward, to find air there" (19). The narrow white walls were "like very rapid beats" that made one feel "as if a game, where one's life is at stake, were played" which forced one "to sudden ascents, to improbable climbs, and to all prominent points" (19). Seeming to return to the etymology of the Greek peripteron, with its image of feathers, he continued:

They are like a fluttering of wings: thin pilasters which seem to detach themselves from the wall to vibrate alone. Seeing them in a row, it is as if the equal tempo that separates them were frenetically accelerated: the

Fig. 3 Edoardo Persico, Marcello Nizzoli and Lucio Fontana (1936). Hall of Honour, Palazzo dell'Arte, Milan. Axonometric from competition board. [Edoardo Persico Scritti d'architettura (1927/1935), ed. Giulia Veronesi, Vallecchi Edittore, Florence, 1968: 196]
5 An antifascist, Giolli wrote for clandestine newspapers. On 14 September 1944 , he was arrested with his wife and son, was tortured and taken to the prison of S. Vittore in Milan, then deported to Mauthausen, in Austria, where he died at the camp of Gusen 2 on the night of 5 or 6 January 1945.

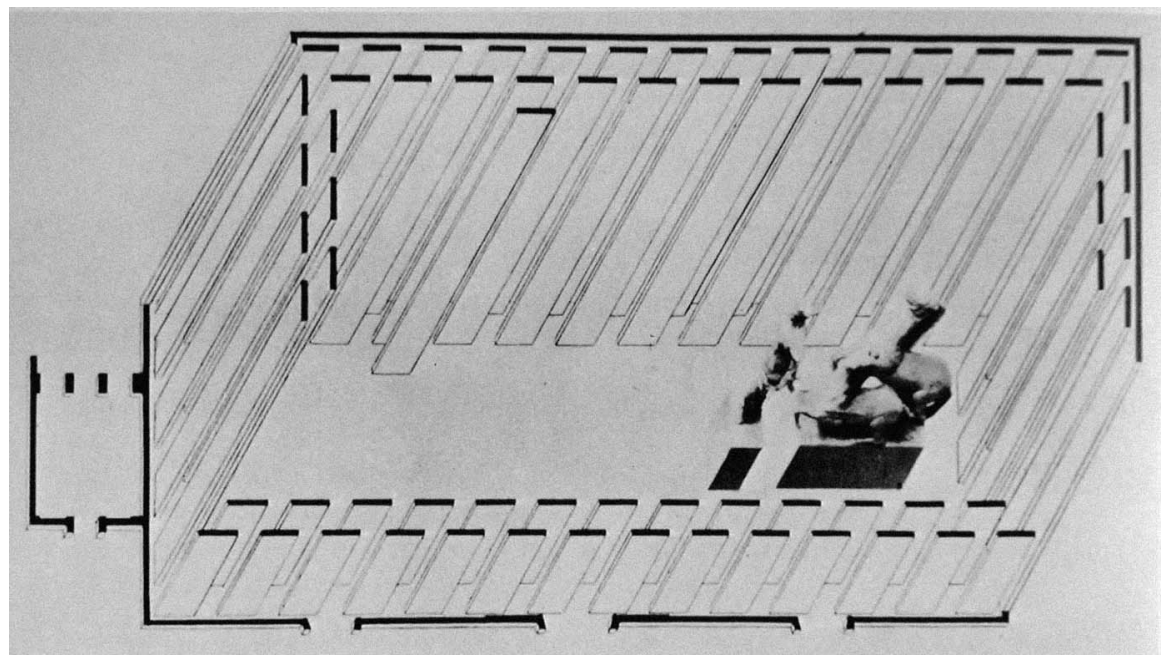




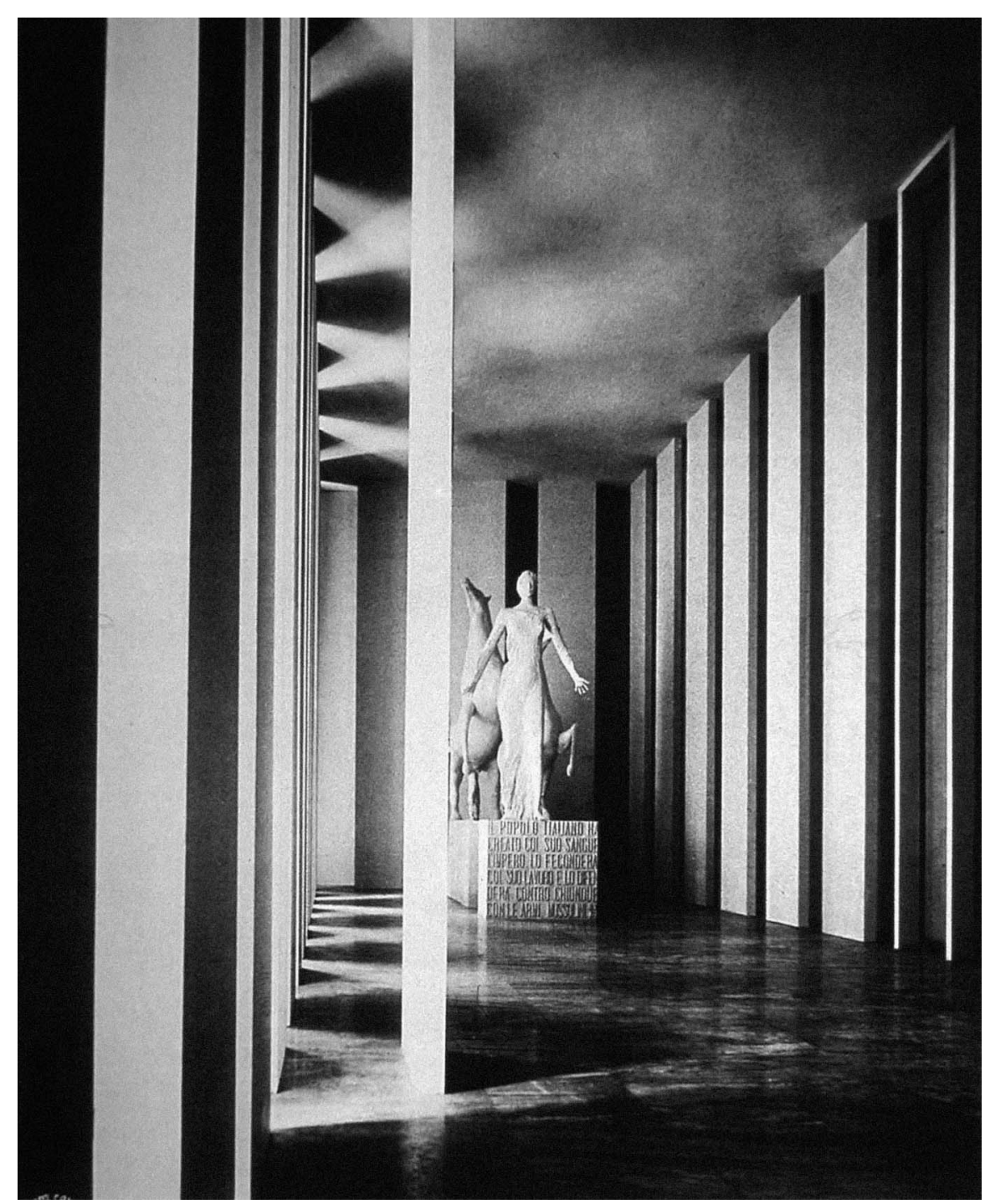

beats became ever more rapid, disquieting. As when everyone clap their hands around a dancer with an ever quickening beat that gets into the blood to the point of dizziness. (19)

He compared the screens to the colonnades of Greek temples: "They were like a magic belt around the sacred hall", creating "an intermediate atmosphere, imprisoning the air [...] a band of secret atmosphere that went around the closed little rectangle, an isolation belt" (18). They let the air pass "as if through a grill" (18) that serves as a passage from black to white, from empty to full.

Filtering through the "constant frenetic appearing of these excited white screens", Giolli sought "breathing space and peace", finding it only when "suddenly two large horizontal planes appear, one down low, the other high up; matching, parallel, gliding, launched as if in flight": the floor and ceiling. The full volume of the interior is now gained. One has moved from the trembling rhythmic verticality of the periphery to the gliding central space, where the screens now appear to hold the dark planes of floor and ceiling together. Giolli found this counterpoint even more subtle and daring than that between black and white: the two planes "overturn the first pattern: where before black was associated with the perpendicular, now airy planes come alive suspended in the light".

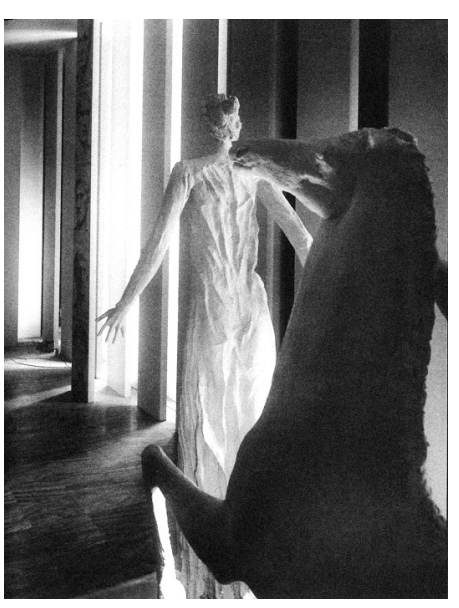

Fig. 4 (left) Edoardo Persico, Marcello Nizzoli and Lucio Fontana (1936). Hall of Honour, Palazzo dell'Arte. [Edoardo Persico: Tutte le opere, ed. Giulia Veronesi, vol. 2. Edizioni di Comunità, Milan, 1964: 150]

Fig. 5 (above) Lucio Fontana (1936). Hall of Honour. [Edoardo Persico: Tutte le opere, ed. Giulia Veronesi, vol. 2. Edizioni di Comunità, Milan, 1964: 151] 
In this enchanted island, island of dream, everything becomes unreal, different in weight, mood, and dimensions. The white figures sculpted by Lucio Fontana also appear as white apparitions, looming out from behind the scenes made of light, born in that world (1936: 20).

The goddess leads the horses, unharnessed and tamed. The elongation of the sculptures matches that of the screens, as the figure's fingers, "vibrating, breathing, most beautiful" (Ponti 1936: 6; see also, Curtis 2008: 28-41) match their vibrating, their breathing. ${ }^{6}$

Something in the work's conception escapes the viewer. Perceptual breakdown points to something beyond perception: the brink of consciousness. The exhibition has no entrance but remains all threshold. One experiences an event without actualisation: only a presage. What is intimated is the possibility of space, at the threshold between being and non-being, as atmosphere and clearing.

\section{Aerated diagrams: Albini's Hall of Aerodynamics}

Albini's contribution to the Exhibition of Italian Aeronautics consisted of an Aerodynamics section, the most scientific and didactic of the show, dealing with fundamental principles of the movement and up-lift of bodies in air. His design made the laws of aerodynamics visible and accessible. ${ }^{7}$ On a screen of square frames with mesh running along the centre of the room, diagrams represented specific characteristics of aerodynamic profiles, details, microphotographs and installations of experimental laboratories. Four large graphs on mesh set transversally at intervals along the length of the hall displayed the curvatures of four characteristic types of plane. Currents of smoke generated in the wind tunnel were shown by stroboscope in a corner of the hall as aerodynamic phenomena related to the form of the envelope and movement of propulsion.

On approaching Albini's section of the exhibition, visitors saw screens of floorto-ceiling grids in white painted steel mesh simultaneously at first, five deep with an arabesque of diagrams, vibrating in moiré through superimposition. On

6 Commenting on the effects of vertical drapery in sculpture, Bachelard notes: "We can never spend too much time meditating on the expression an elongated form, which is an image in which formal and material imagination intersect. [...] an elongated form is a formal élan [...] It is to be noted that any elongated form reaches out towards the heights, towards light. The elongated form is a formal élan that unfolds in pure, luminous air. We could not conceive of an elongated form going downward, suggesting a fall. That would be in the realm of the imagination - aerodynamically absurd." (Bachelard 1988: 76)

7 The comparison with Le Corbusier's treatment of the same material a year later in his Aircraft (illustrations 50, 51, 52) is instructive: there the technology of flight, aerodynamics, is nowhere explained.

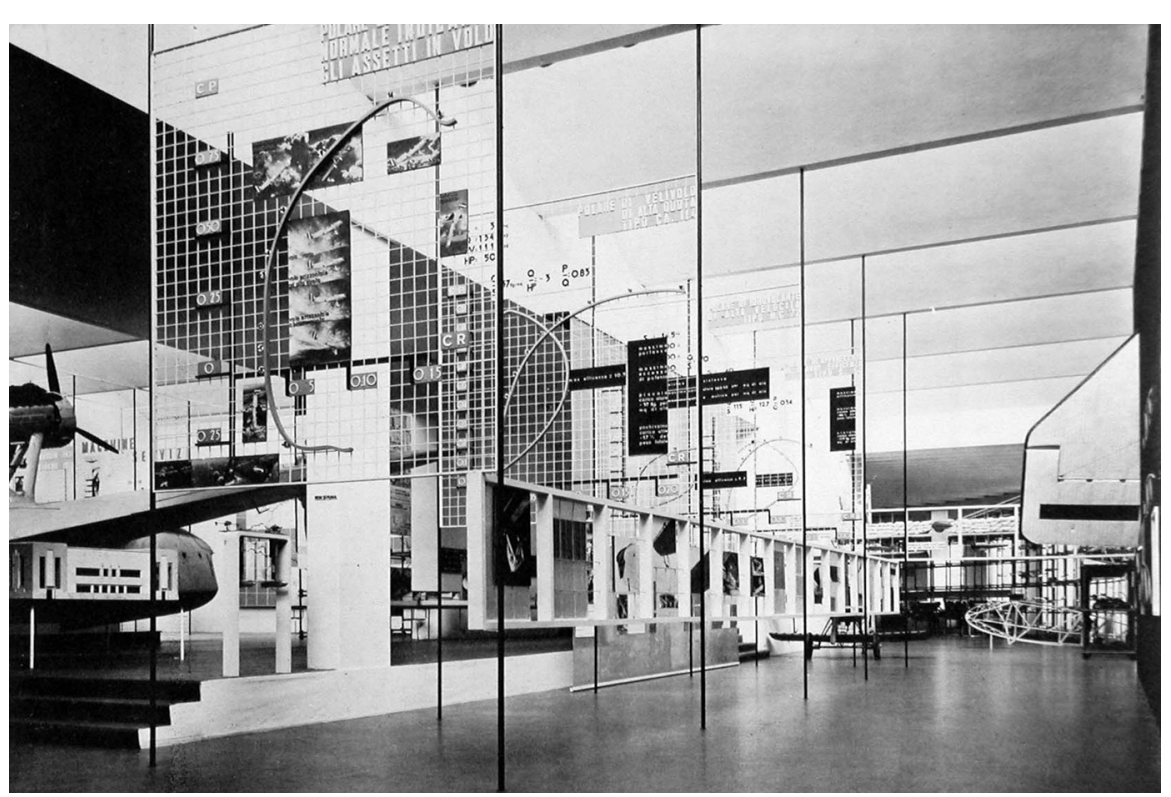

Fig. 6 Franco Albini (1934). Hall of Aerodynamics, Exhibition of Italian Aeronautics, Milan, Palazzo dell'Arte [Courtesy Fondazione Franco Albini] 
advancing, they appeared sequentially; to their right, images and skeletal sections were mounted on wiry uprights, detached from the wall, an open horizontal ladder-form, on its side, but vertical and suspended longitudinally through the hall, led to a background of open scaffolding. These elements together, interwoven as discrete lines, tones and hues, dilated the space imbuing it with the quality of plein air. Marcello Fagiolo observes of the exhibition in general that "an inversion of traditional values was presented: the aeroplane-objects were for the most part static, dark and yet exhibited in fragments ... while paradoxically the structures exhibited were to free themselves and levitate in an oneiric sky” (1981: 38).

The aerodynamics hall combined graphic intensity with spatial dispersion. The metallic cages, struts and fragile supports dissolved finite contours into atmosphere. It was an atmosphere fabricated of structure, passing from the diagrammatic structures of air to an aerial structure. The exhibit's content, the flow and disturbance of air (delimiting by filaments the rational principles of this unbounded, fickle, and invisible medium) became the vehicle for the creation of a space of that very medium. Air was the subject, air the effect, air the medium - sober objectivity was carried to shimmering evanescence.

\section{Atmospheric spaces}

In 1942, Albini wrote of an "aesthetic of modernity" which is made of "a maximum lightness of densities (spessori), an extreme fluidity of forms, an almost unconditioned overcoming of the sense of volume and weight" (1942: 12-13). These airy qualities were introduced in Futurism as early as Prampolini's notion of "atmospheric densities" in his Futurist 'Atmosphere-structure'. ${ }^{8}$ Albini's installations from 1935 to 1960, however, tend to the experience of a linear abstraction, subtle to the point of being almost purely graphic and animated by contact with an "atmospheric sensibility" of space rather than that of solid materials. A colleague, discussing Albini's apartment in Milan, emphasised an "essentially spatial" expression, repeatedly using the phrase "atmospheric spaces (spazi atmosferici)" to characterise its rooms, "delimited ideally even just by hints" (Romano 1941: 14). Such works are the legacy of Impressionism and the spatial interpenetration of Crystal Palace. They make atmosphere perceptible as a poet might speak of the ineffable.

Albini's expression of void space involved structural cages and grids, the detachment of elements expressed paratactically, with a minimum of touching, as splits and "negative" details through which air passed, as well as the hygienist tradition of fresh air and light. These conceptions of space are augmented later by the sensation of "plunging into the air" in the Living Room in a Villa, and of being out in the open, achieved through the penetration of the light and air between gaps, grilles, frames, screens. All this, in combination with the lifting up of elements in compositional play by the lightest of supports, suggests an aerial quality. Carla Zanini related the Living Room in a Villa to three factors: first, certain expressions of abstract art, for which she employs the term (aerial composition), composizione aerea; secondly, an "Impressionist sensibility"; and thirdly, a "desire for fusion with nature" (1941: 34). ${ }^{9}$

This aerial ambience is, unfortunately, largely lost in the black and white images of Albini's works that remain today. As Veronesi cautioned with regard to Persico's Sala delle medaglie d'oro, "the photographs allow us to grasp only the linear schema” (1953: 108). More evident, in many of Albini's pre-war works, is their dependence on a system of spatial co-ordinates, grids and frames so typical of

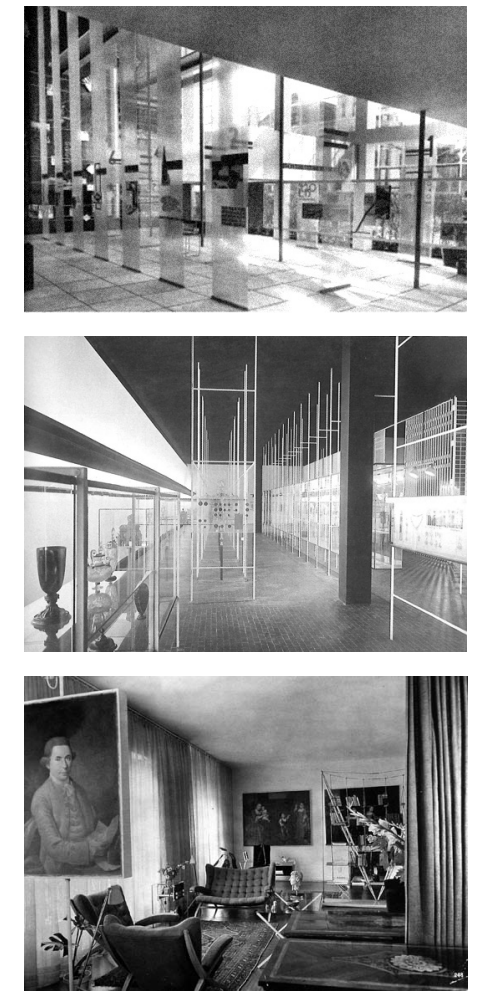

Fig. 7 Franco Albini (1935). Interior of Permanent INA Pavilion, Milan Trade Fair [Courtesy Fondazione Franco Albini]

Fig. 8 Franco Albini and Giovanni Romano (1936). Antique Gold Work Exhibition, Milan Triennale, Palazzo dell'Arte, Milan [Courtesy Fondazione Franco Albini]

Fig. 9 Franco Albini (1941). Albini Apartment, Via de Togni, Milan [Courtesy Fondazione Franco Albini]
8 Prampolini proposed a "Futurist 'Atmosphere-structure' - Basis for an Architecture 1914-15" (Apollonio 1973: 181-183) see also Crispolti 1984: 14, and Godoli 1997: 1-3. He aimed to create new architectural forms by materialising "atmospheric dynamism" through human activities see Lista 2001: 172-73.

9 Zanini makes reference here to Persico's Turin lecture, "Prophecy of Architecture" with its derivation of modern architecture from Impressionism rather than, as Lionello Venturi maintained, from Cubism (Zanini 1941: 34). 


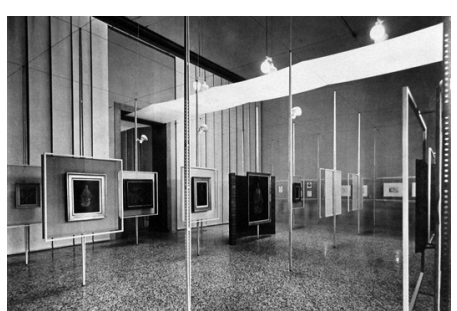

Fig. 10 Franco Albini (1941). Scipione \& Black and White Exhibition, Pinacoteca di Brera, Milan. Props and frames define erased walls, suspended paper a route [Courtesy Fondazione Franco Albini]
10 Irace refers to Birolli 1983: 124

11 By contrast, as Labò noted on the occasion of its 90th anniversary, at Crystal Palace, "[t]he object is of value only for its presence; and no one sees that the setting, the breath, can enhance vitality." (1941: 9)
Neo-Plasticism and Italian Rationalism. Together with the airy ambience described by reviewers, they were a product of both a linear, graphic conception and painterly atmosphere - abstraction and impressionism. Carla Albini described her brother's work in 1943 as representative of a tendency in which "the experience of a linear abstraction, subtle to the point of graphism, is animated by contact with an atmospheric sensibility, which uses spatial values more than true and proper building values" (quoted in Albini 2006: 207-08).

Even apparent emptiness produces atmosphere. Fulvio Irace writes that it was "perhaps the metaphysical vein of the Italian vocation to abstraction, as Zeno Birolli observed that was expressed in the notion of spazio vuoto (empty space) wherein to make float the 'plastic solitude' of a new world of objects" (2006: 20). ${ }^{10}$ In the rationality, common sense or plain banality of domestic space, Albini stages a secret spirituality, close to the idealism of Franco Ciliberti's Valori Primordiali, to which it would not have been foreign. Here then the double nature of his work re-emerges. The objects dematerialise, their constructive character dissolving into light and colour. This aspect of Albini's architecture, which his sister termed "chromaticism", was not simply a decorative value but in her words an "architectural principle", so that (as Veronesi before her had found blue in black and white) she regarded even his monochromatic Mostra di Scipione \& Black and White, 1941, as "resolved on the chromatic level. Architecture of air and in this sense exactly the most coherent representation of this taste to which Persico pointed" (quoted in Albini 2006: 208).

\section{Acclimatising: The space of relation}

In a lecture, "My experience as architect in exhibitions in Italy and abroad" (195455), Albini described an exhibition in São Paolo, whose spaces were defined by semi-transparent screens, where "the successive transparencies, on the opaque grid of the structure of frames, stamped a vibration which could be felt on the air and light" (2006: 77). After the war, the dissolution of architecture into air, light and "colour" in his exhibition and installation works became subsumed into his museum design. Here, in their moods and affects, atmosphere developed into the very conditions of the exhibits' appearing.

In another lecture, "The functions and architecture of the museum: some experiences” (1954-55), Albini himself proposed it was only in the post-war period that architecture sought relationships with the works exhibited and with the public. ${ }^{11}$ A new function was born: that of promoting public contemplation of the art work "in its essentially aesthetic values" (2006: 72). This new function, Albini suggested, found its architectural expression in ambientamento, an almost untranslatable word which implies acclimatising, setting, settling in, giving an ambience or environment to something. In these pioneering ideas, Albini and his colleague Carlo Scarpa proceeded apace. The concept of (setting) ambientare brought the visitor "closer to the artwork through a language consistent with his sensibility" (72). Albini continued, "Architecture creates a modern atmosphere around the visitor and precisely because of this enters into rapport with his sensibility, culture, and mentality as modern man. [...] architecture provides precisely the first captivation of the work of art" (72).

Albini noted that, for a successful and interesting exhibition, it is sometimes fundamentally important to detach the visitor from the reality outside and thus to "introduce (an ambience of a particular atmosphere) un ambiente di atmosfera particolare helping him concentrate attention on the works exhibited and making his 
feeling acute" (76). Thus what he calls "the exhibition invention" should attract the visitor in its play, arousing "atmosphere around the works most adapted to valorise them yet without ever overwhelming them" (76). Going further, he argued that "to make the ambience a potent element of suggestion", one must have recourse to spatial rather than plastic, that is to say, solid solutions: "it is precisely the voids that must build, air and light being the building materials. The atmosphere must not be fixed or stagnant but pulsate and the public must find itself immersed here and stimulated without noticing it (76).”

To perceive space is first to perceive a hitherto unnoticed medium, gap or void. This perception involves overturning of attention. The call to and recognition of space, as opposed to objects and things in themselves, is the aesthetic moment, par excellence. It is the recognition of space as a space of relationships, whose material co-relative, or "embodiment", is air. On the conjunction of art and space in Chillida's sculpture and Heidegger's philosophy, Andrew Mitchell writes that both,

...seek a space that would no longer be void but would be traversed by tension and the vibration of form, a space permeated by the things

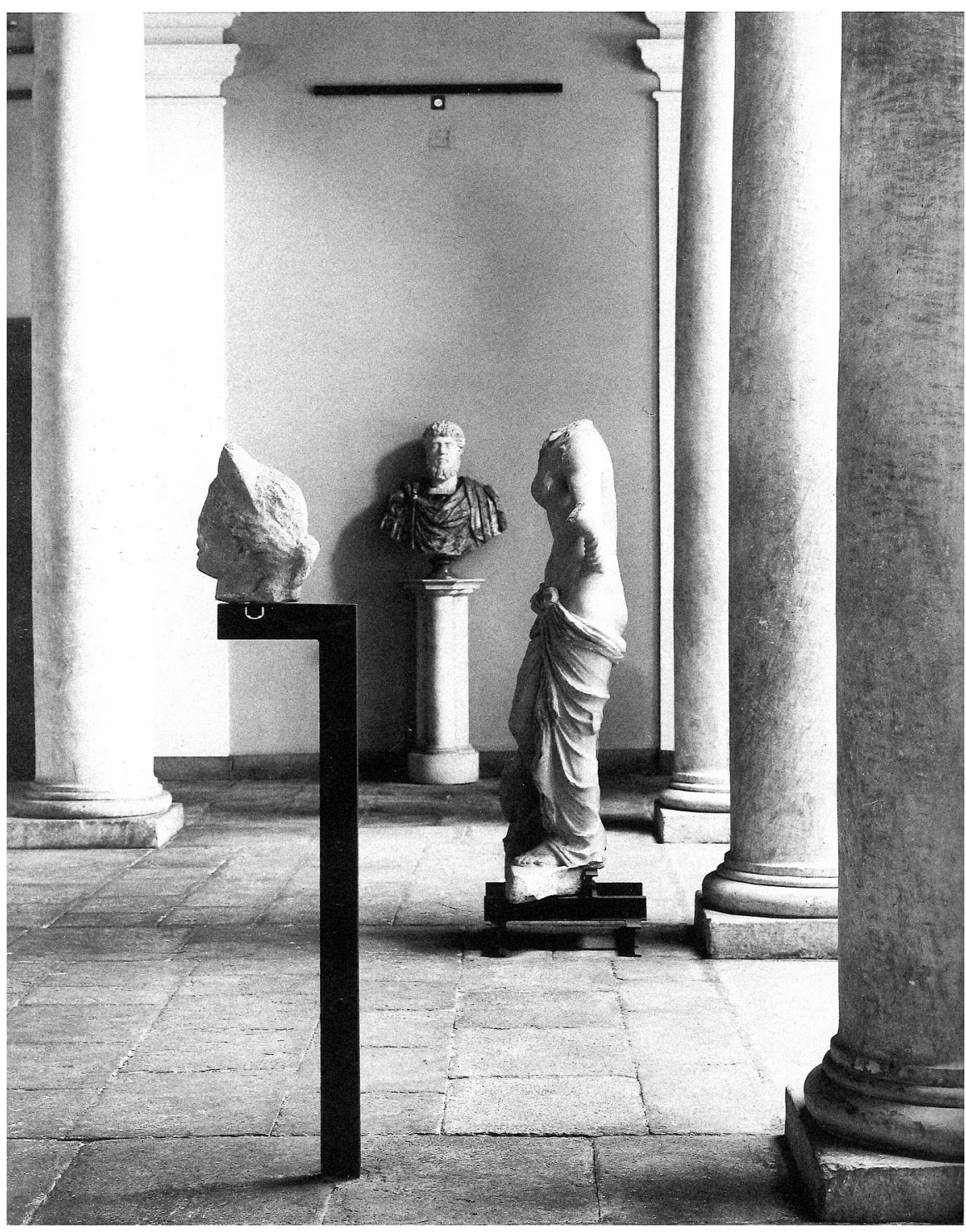

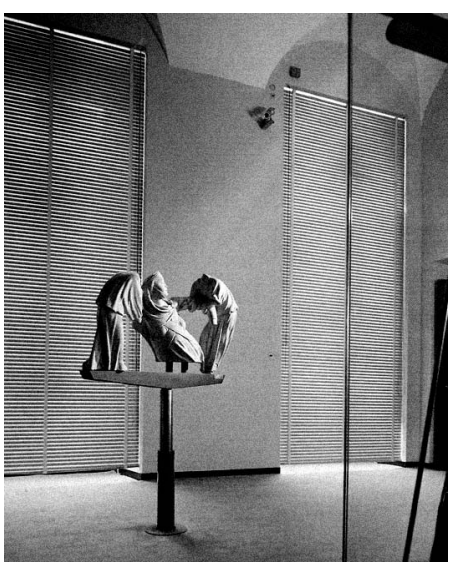

Fig. 11 (left) Franco Albini \& Franca Helg (1949-51). Palazzo Bianco, setting with interactive mounting for Margaret of Brabant Group. [Courtesy Fondazione Franco Albini]

Fig. 12 (above) Franco Albini \& Franca Helg (1949-51). Palazzo Bianco: Apollo and Venus with polychrome Roman Head [Courtesy Fondazione Franco Albini] 
Fig. 13 (left) Franco Albini \& Franca Helg (1952-56). Museum of the Treasury of San Lorenzo, Genova [Courtesy Fondazione Franco Albini]

Fig. 14 (right) Franco Albini \& Franca Helg (1952-56). Museum of the Treasury of San Lorenzo, Genova. The sculpture of St Laurence, its shadow and the shattered hexagonal plate beyond, once taken to have been the Holy Grail, now presented as radio telescope [Courtesy Fondazione Franco Albini]
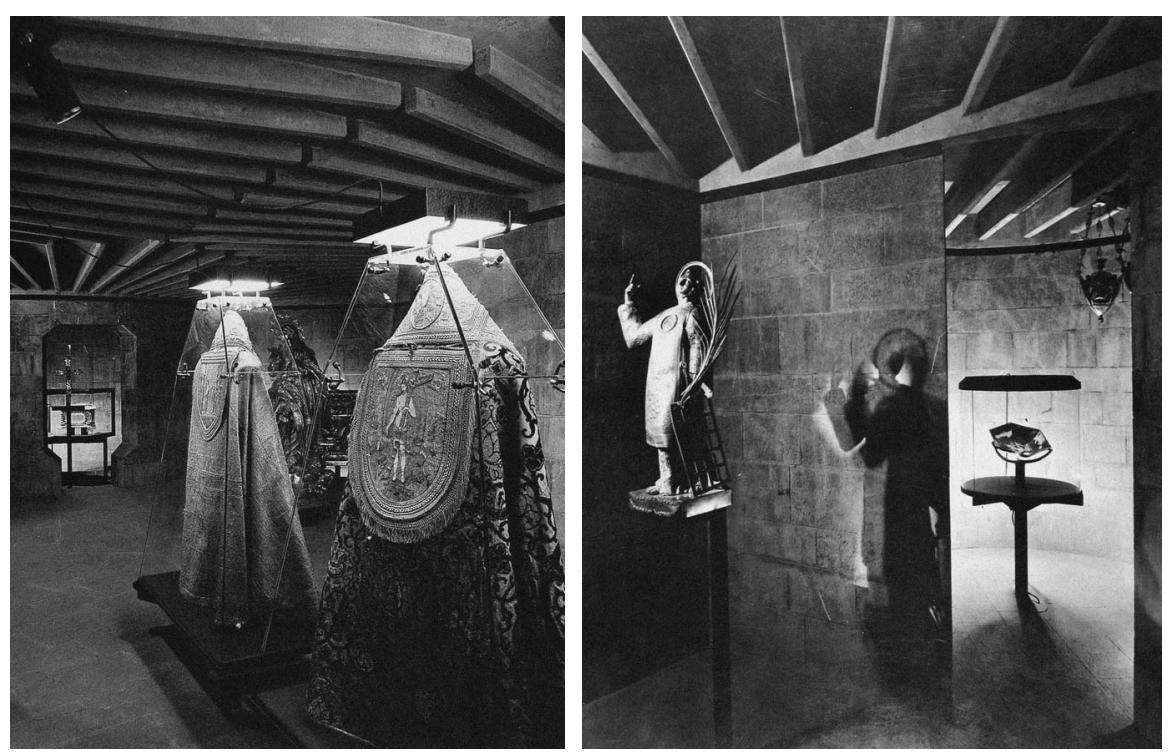

that take place throughout it, a poetic space of relation accomplished through the incorporation of space into the sculpture and the incorporation of sculpture into space (2010: 69).

Here the making of sculpture involves a spacing-apart where a relation between the separated parties persists. Thus, spacing is "a way of thinking this connectivity of things in the world" and "the admission into space is a giving of the thing to relation" (2010: 70). Heidegger's essay went a long way towards thinking the conjunction between the plastic arts and space. One thing, however, seems missing in his account - persons perceiving the work, if there are any, are not in the presence of their own bodies. For all the attention to place, region and context, subjective involvement with sculpture and location leaves no trace on Heidegger's conception of that conjunction: the perceiver remains unaffected. To recognise the subjective would be to consider that, as Böhme reminds us, atmosphere is a,

... fundamental fact of human perception, that is, the perception through which man senses in his (condition) Befinden simultaneously (where he is located) wo er sich befindet. Seen this way, atmospheres are something that define the human being-in-the-world as a whole, i.e. his relationship to environments, to other people, to things and works of art. $(2006: 105)^{12}$

In architecture, as Böhme writes, "it is never only a matter of giving form to an object, but always of creating at the same time the conditions of its appearing" (2000: 98).

The fame of Italy's post-war museums and exhibitions is in large measure attributable to Albini and his colleagues as protagonists of the conception and making of these settings. Albini's notion of space as rapport is an attuning, an acclimatising, of the body to the works exhibited, focusing and interpreting them through an "ambiente di atmosfera particolare (ambience of a particular atmosphere)" (2006: 76). Such an aesthetics of atmosphere refocuses attention that was previously (and is still today) distorted by an ontology oriented to the thing and reconfirms a different orientation: "the object and goal of aesthetic work is literally nothing; i.e. that which lies ‘between' - the space” (Böhme 1998: 115). 


\section{References}

Albini, F. (1942). Materiali autarchici e il gusto. Cellini, Rivista dell'artigianato italiano, II, n. 4, January, 12-13.

Albini, F. (2006). "Le funzioni e l'architettura del museo: alcune esperienze”. In F. Bucci \& F. Irace (Eds.), Zero gravity: Franco Albini : costruire le modernità. Milan, Italy: La Triennale di Milano: Electa. Albini, F. (2006). “Le mie esperienze di architetto nelle esposizioni in Italia e all'estero". In F. Bucci \& F. Irace (Eds.), Zero gravity: Franco Albini : costruire le modernità. Milan, Italy: La Triennale di Milano: Electa.

Albini, M. (2006). Evoluzione di una poetica. In F. Bucci \& F. Irace (Eds.), Zero gravity: Franco Albini: costruire le modernità (pp. 71-73). Milan, Italy: La Triennale di Milano : Electa.

Astarita, R. (1998). Anna Maria Mazzucchelli: Alongside Persico and Pagano. Architettura, 44 (513-514, July-August), 467-472.

Bachelard, G. (1988). Air and Dreams. Dallas, TX: Dallas Institute Publications.

Barbaro, D. (1556). I Dieci Libri dell'Architettura tradotli e commentati da Daniele Barbaro.

Venice, Italy.

Birolli, Z. (1983). Sorbi Tordi e Nitidenze. Arte in Italia dopo la Metafisica. Milan, Italy: Jaca Book.

Böhme, G. (1998). Atmosphere as an Aesthetic Concept. Daidalos, 68, 112-115.

Böhme, G. (2000). Atmosphäre. Essays zur neuen Ästhetik. Frankfurt, Germany: M. Suhrkamp.

Böhme, G. (2003). Wetter und die Gefühle. Für eine Phänomenologie des Wetters. In B. Busch

(Ed.), Luft (pp. 148-161). Bonn, Germany: Kunst- und Ausstellungshalle der BRD.

Böhme, G. (2006). Architektur und Atmosphäre. Munich, Germany: Wilhelm Fink.

Bucher, L. (1851). Kulturhistorischer Skizzen aus der Industrieaustellung aller Völker.

Frankfurt, Germany.

Connor, S. (2010). The matter of air: Science and the art of the ethereal. London, England:

Reaktion Books.

Crispolti, E. (1984). Attraverso L'Architettura Futurista. Modena, Italy: Fonte d'Abisso.

Curtis, P. (2008). Patio and pavilion: The place of sculpture in modern architecture. Los Angeles, CA: J. Paul Getty Museum.

Fagiolo, M. (1981). Genesi di un linguaggio. L'astrazione magica di Albini e la 'via italiana' al design e delle esposizioni (1930-1945) Franco Albini 1930-1970 (pp. 28-44). New York, NY: Rizzoli..

Forster, T. (1815). Researches about Atmospheric Phaenomena. London, England: Baldwin, Cradock \& Joy.

Forty, A. (2000). Words and buildings : A vocabulary of modern architecture. London, England: Thames \& Hudson

Futurist Manifestos. (1973). New York, NY: Viking Press.

Giedion, S. (1943). Space, Time and Architecture: The growth of a new tradition (First edition, fourth printing ed.). Cambridge, MA: Harvard University Press.

Giolli, R. (1936). VI Triennale di Milano: ‘La Sala della Vittoria'. Casabella (102-103 June-July), 14-21.

Godoli, E. (1997). // Futurismo (3rd ed.). Roma-Bari, Italy: Laterza.

Gregotti, V. (1987). Milano e la cultura architettonica tra le due guerre. In C. D. Seta (Ed.), Edoardo Persico. Napoli, Italy: Electa.

Hamblyn, R. (2001). The Invention of Clouds: How an Amateur Meteorologist forged the Language of the Skies. New York, NY: Picador.

Heidegger, M. (1973). Art and Space. Man and World(6), 3-8.

Heidegger, M. (1983). Die Kunst und der Raum. Gesamtausgabe, Band 13 (pp. 203-210). Frankfurt, Germany: Klosterman.

Hildebrand, A., von. (1918). Das Problem der Form in der bildenden Kunst. Strassburg, Germany: Heitz \& Mondel.

Hill, J. (2012). Weather Architecture. London, England and New York, NY: Routledge.

Ingold, T. (2005). The eye of the storm: Visual perception and the weather. Visual Studies,

20( 2), 97-104

Ingold, T. (2011). Being alive: Essays on Movement, Knowledge and Description. Abingdon, England: Routledge.

Ingold, T. (2012). Atmospheres and weather. In J. Brouwer, A. Mulder \& L. Spuybroek (Eds.), Vital Beauty: Reclaiming Aesthetics in the Tangle of Technology and Nature. Rotterdam, Holland: NAi Publishers/V2.

Ingold, T. (2013). The Atmosphere. Chiasmi International, 14 (75-87).

Irace, F. ( 2006). Macchine celibi. In F. Bucci \& F. Irace (Eds.), Zero gravity: Franco Albini : costruire le modernità. Milan, Italy: La Triennale di Milano: Electa. 
Jankovic, V. (2000). Reading the Skies: A Cultural History of English Weather, 1650-1820. Manchester, England: Manchester University Press.

Jones, O. (1863). Lectures on architecture and the decorative arts. London, England: Strangeways \& Walden.

Jullien, F. (2009). The Great image has no Form or the Non-Object of Painting, Chicago, IL and London, England: University of Chicago Press.

Labò, M. (1941). Il gusto dell'ottocento nelle esposizioni. Casabella (March-April), 4-30.

Lista, G. (2001). Le Futurisme: Création et avant-garde. Paris, France: Les Éditions de l'Amateur. Lucae, R. (1869). Über die Macht des Raums in der Baukunst. Zeitschrift für Bauwesen, 14, 294-306.

Mazzucchelli, A. M. (1934). Stile di una mostra, in Mostrare: L'allestimento in Italia dagli anni Venti agli anni Ottanta, Milan, Lybra Immagine, pp.532-535 [originally published in Casabella(80 August), 6-9.

Merrifield, M. P. (1970). Essay on the Harmony and Contrast of Colours as Exemplified in the Exhibition, The Arts Journal Illustrated Catalogue: The Industry of All Nations, 1851 (pp. i-viii). London, England: David \& Charles.

Meyer, P. (1936). Notizen von der VI. Triennale Mailand. Das Werk (10 October) 312-16.

Mitchell, A. J. (2010). Heidegger Among the Sculptors : Body, Space and the Art of Dwelling. Redwood City, CA: Stanford University Press.

Olwig, K. (2011). All that is landscape is melted into air: the 'aerography' of ethereal space. Environment and Planning D: Society and Space, 29(3), 519-532.

Persico, E. (1932). Un interno a Milano. La Casa Bella, VI(no. 6, June).

Persico, E. (1964). Edoardo Persico Tutte le Opere. Milan, Italy: Edizioni di Communità.

Persico, E. (1968). Scritti d'architettura (1927/1935) (Vol. 2). Florence, Italy: Vallecchi.

Persico, E. (1977). Edoardo Persico: Oltre l'Architettura, Scritti Scelti e Lettere. Milan, Italy.

Ponti, G. (1936). La Sala della Vittoria. Domus (103, July).

Prada, M. d. (2009). Arte y vacío: Sobre la configuración del vacío en el arte y la arquitectura. Buenos Aires, Brazil: Nobuko.

Romano, G. (1941). La casa di un architetto. Domus (163), 9-17.

Schmarsow, A. (1994). The Essence of Architectural Creation (Das Wesen der architektonischen Schöpfung). In H. F. Mulgrave \& E. Ikonomou (Eds.), Empathy, Form, and Space: Problems in German Aesthetics 1873-1893 (pp. 281-297). Santa Monica, CA: The Getty Center for the Arts and the Humanities.

Semper, G. (2004). Style in the Technical and Tectonic Arts; or, Practical Aesthetics (H. F. Mallgrave \& M. Robinson, Trans.). Los Angeles, CA: Getty Research.

Sloterdijk, P. (2011). Architecture as an art of immersion. Interstices: Journal of Architecture and Related Arts, 12, 106-109.

Solà-Morales, I., de. (1996). Differences: Topographies of Contemporary Architecture. Cambridge, MA: MIT Press.

Thornes, J. E. (1999) ). John Constable's skies: A fusion of art and science. Edgbaston, England: The University of Birmingham Press.

Thornes, J. E. (2008a). Cultural climatology and the representation of sky, atmosphere, weather and climate in selected art works of Constable, Monet and Eliasson. Geoforum 39, 570-580.

Thornes, J. E. (2008b). A Rough Guide to Environmental Art. Annual Review of Environment and Resources, 33, 391-411.

Valéry, P. (1960 (1921)). Eupalinos ou l'Architecte, Fuvres (Vol. II, pp. 79 - 174). Paris,

France: Gallimard.

Vasari, G. (1550). Le Vite de' piú eccellenti architetti, pittori, et scultori italiani, da cimabue insino a' tempi nostri, from http://bepi1949.altervista.org/vasari/vasari94.htm

Veronesi, G. (1953). Difficoltà politiche dell'architettura in Italia 1920-1940. Milan, Italy: Libreria Editrice Tamburin.

Vischer, R. (1994). On the optical sense of form: a contribution to aesthetics. In H. F. Mulgrave \&E. Ikonomou (Eds.), Empathy, Form, and Space: Problems in German Aesthetics 1873-1893 (pp. 8993). Santa Monica, CA: The Getty Center for the History of Art and the Humanities.

Zanini, C. (1941). A proposito di un arredamento esposto alla VII Triennale. Costruzioni-Casabella (157, January), 34-40.

Zevi, B. ([1950] 1975). Storia dell'architettura moderna. Turin, Italy: Einaudi. 